\title{
MENINGKATKAN KEMAMPUAN BERBICARA ANAK USIA 4-5 TAHUN MELALUI KEGIATAN CIRCLE TIME
}

\author{
Rena Agustiana ${ }^{1}$,Fitri Ramadhini ${ }^{2}$ \\ Universitas Negeri Jakarta', IAIN Padangsidimpuan²
}

Email : agustianarena@gmail.com¹, f.ramadhini@gmail.com²

\begin{abstract}
Abstrak :Penelitian ini bertujuan untuk meningkatkan kemampuan berbicara anak usia 4-5 tahun. Penelitian dilaksanakan di PAUD Tunas, Jakarta Selatan. Subjek penelitian adalah anak usia 4-5 tahun di PAUD Tunas yang mempunyai masalah dalam kemampuan berbicara yaitu sebanyak 10 orang. Metode penelitian yang digunakan adalah penelitian tindakan kelas dengan menggunakan model Kemmis dan Taggart. Pengumpulan data menggunakan tes dan non tes untuk memperoleh data tentang data pelaksanaan tindakan. Data kemampuan berbicara anak dilakukan melalui beberapa teknik yaitu, catatan lapangan, lembar instrumen observasi, catatan wawancara, dan catatan dokumentasi.Validitas instrumen menggunakan expert judgement dengan dosen yang ahli pada bidang bahasa.Analisis data kualitatif diperoleh melalui reduksi, display, dan verifikasi.Pada akhir siklus II, kemampuan berbicara anak mengalami peningkatan.Anak sudah mampu menjawab pertanyaan dari peneliti dengan tepat.Hampir semua anak sudah berkembang dalam menyatakan sesuatu dengan lancar dan telah dapat menggunakan kata ganti orang, waktu, dan tempat ketika berbicara.Anak mulai berkembang dalam kemampuan mengajukan pertanyaan.Anak juga sudah mulai berkembang dalam hal bahasa tubuh dan intonasi yang sesuai ketika berbicara. Analisis data kuantitatif diperoleh dari hasil perbandingan antara kemampuan berbicara sebelum dan sesudah pelaksanaan tindakan. Hasil penelitian pada siklus I menunjukkan presentase sebesar 51\%, pada akhir siklus II meningkat menjadi 76\%.Hasil akhir dari keseluruhan analisis presentasi data adalah peningkatan sebesar 25\%. Implikasi dari hasil penelitian ini adalah bahwa penerapan kegiatan circle time dapat dijadikan alternatif untuk meningkatkan kemampuan berbicara anak usia 4-5 tahun di PAUD Tunas, Jakarta Selatan.
\end{abstract}

Kata Kunci: Circle Time, Kemampuan Berbicara, Anak Usia 4-5 Tahun

Abstract :This study aims to improve the speech of children aged 4-5 years. The experiment was conducted in PAUD Tunas, South Jakarta. Subjects were children aged 4-5 years in PAUD Tunas have problems in the ability to speak as many as 10 people. The method used was a class action research using a model Kemmis and Taggart. Collecting data using test and non-test to obtain data about data implementation of the action. Children's speech data was done through several techniques, there are, field notes, sheet instruments observation, interview notes, and documentation notes. The validity of the instrument using expert judgment with lecturers who are experts in the field of language. Analysis of qualitative data obtained through reduction, display, and verification. At the end of the second cycle, the ability to speak of the children has increased. Children are able to answer questions from researcher appropriately. Almost all children are already grown in stating something smoothly and has been able to use personal pronouns, time, and place when speaking. Children begin to develop the ability to ask questions. Children have also begun to develop in terms of body language and intonation appropriate when speaking. Analysis of the quantitative data obtained from the results of the comparison between the ability to speak before and after the implementation of the action. The results of the study in the first cycle shows a percentage of 51\%, at the end of the second cycle increased to 76\%. The final results of the overall analysis of data presentation is an increase of $25 \%$. The implication of these results is that the application of circle time activities can be used as an alternative to increase the speech of children aged 4-5 years in PAUD Tunas, South Jakarta.

Keywords: Circle Time, Speech, Children Aged 4-5 Years 


\section{PENDAHULUAN}

Anak merupakan anugerah yang diberikan oleh Tuhan.Anak perlu dijaga dan dididik agar potensinya dapat berkembang.Potensi yang dimilki anak perlu digali untuk menentukan masa depannya. Potensi anak dapat berkembang jika semua kebutuhan anak dipenuhi dengan sebaik-baiknya. Kebutuhan anak merupakan sesuatu yang harus didapatkan oleh anak.

Kebutuhan anak yang harus dipenuhi adalah kebutuhan cinta kasih dari orang tua, pujian dari prestasi, kebebasan untuk menjadi dirinya sendiri dan kebebasan untuk mengeluarkan pendapat, serta kebutuhan akan pendidikan. Kebutuhan tersebut didapatkan dengan diiringi pemenuhan kewajiban yang harus dijalankan oleh anak. Jika semua kebutuhan telah terpenuhi, maka perkembangan anak akan berkembang dengan baik. Perkembangan yang dimiliki anak, yaitu perkembangan fisik motorik, kognitif, bahasa, dan sosial emosional.

Di antara perkembangan anak tersebut, perkembangan bahasa merupakan perkembangan dasar yang mempunyai peran cukup penting karena bahasa dipergunakan pada sebagian besar aktivitas yang dilakukan. Pada perkembangan bahasa, terdapat 4 aspek keterampilan di dalamnya, yaitu keterampilan menyimak (listening skill), berbicara (speaking skill), membaca (reading skill), dan menulis (writing skill). Keempat aspek keterampilan bahasa tersebut saling berhubungan satu sama lain. Mula-mula anak belajar menyimak apa yang diucapkan orang lain kemudian anak belajar untuk berbicara. Setelah itu, anak mulai belajar untuk mengembangkan kemampuan membaca dan menulis. Setiap keterampilan berhubungan erat dengan proses berpikir yang mendasari bahasa.

Berdasarkan aspek keterampilan bahasa, berbicara merupakan aspek bahasa yang cukup penting bagi anak karena anak dapat menyatakan apa yang dirasakan kepada orang lain. Berbicara juga dapat digunakan untuk menyatakan setuju atau ketidaksetujuan pada sesuatu, sehingga dengan berbicara, orang lain akan mengetahui apa yang diinginkan. Selain itu dengan berbicara, maka kosakata anak akan mengalami pertambahan.

Berbicara digunakan untuk melakukan interaksi dengan orang lain dan untuk mengungkapkan apa yang dipikirkan. Berbicara dapat membantu anak dalam berinteraksi dengan teman sebaya dimana anak akan saling memperkenalkan diri dan bercerita mengenai pengalaman. Berbicara juga dapat digunakan anak untuk berinteraksi dengan orang dewasa untuk mengungkapkan apa yang diinginkan. 
Keterampilan berbicara anak akan terus meningkat. Pada awalnya, anak hanya mengekspresikan sesuatu dengan menggunakan suara saja, selanjutnya anak dapat mengekspresikan sesuatu dengan berkomunikasi.Komunikasi anak bermula dari menggunakan isyarat dan gerakan untuk menunjukkan keinginan, lalu berkembang menjadi komunikasi dengan menggunakan ujaran yang tepat dan jelas.

Sebelum anak belajar untuk berkomunikasi, anak terlebih dahulu belajar berbicara. Anak belajar berbicara melalui proses penguatan dan peniruan dari orang dewasa. Orang dewasa merupakan faktor pendukung yang sangat penting dalam mengembangkan kemampuan berbicara anak secara eksternal. Orang dewasa yang sering memberikan kesempatan kepada anak untuk berbicara tentang pengalaman, pemikiran, dan perasaannya akan sangat besar manfaatnya dalam mempercepat penguasaan bahasa anak. Orang tua dan guru merupakan orang dewasa yang selalu berada di sekitar anak.

Selain orang dewasa, pendidikan di sekolah termasuk faktor pendukung kedua dalam mengembangkan kemampuan bicara anak.Anak memiliki hak untuk mendapatkan pendidikan. Pendidikan anak usia dini merupakan pendidikan yang diberikan kepada anak sejak usia 0-8 tahun dengan memberikan berbagai rangsangan dalam membantu pertumbuhan dan perkembangan anak. Anak perlu diberikan pendidikan di sekolah agar anak dapat berinteraksi dengan teman sebayanya. Pendidikan di sekolah yang baik adalah melalui bermain dan tanpa paksaan dari siapapun. Anak akan cepat belajar bila tidak ada tekanan. Tujuan utama dari belajar pada masa kecil adalah agar anak merasa gembira dalam belajar.Oleh karena itu, jika anak gembira dalam belajarnya, maka perkembangan anak dapat berkembang secara optimal.

Memberikan pendidikan pada masa-masa usia 4-5 tahun di sekolah dapat membantu anak dalam mengembangkan perkembangan berbicara. Usia 4-5 tahun merupakan masa Golden Age dimana anak dapat menyerap dengan cepat apa yang diberikan. Anak pada usia 4-5 tahun telah menguasai hingga 2100 kata. Anak di usia 4-5 tahun juga dapat menjelaskan cerita mengenai perasaannya dan pengalaman yang dialami serta mimpi dan khayalannya. Oleh karena itu, pendidik perlu memberikan pembelajaran yang menyenangkan dan penuh makna.

Peran pendidik dalam memberikan pembelajaran sangat penting dalam mempengaruhi perkembangan bicara anak. Pendidik yang mengajarkan anak dengan baik, maka anak dapat menerima apa yang diajarkan. Pendidik harus memberikan pembelajaran dengan cara yang 
menyenangkan yaitu melalui bermain, kondusif, dan dapat memungkinkan anak menjadi termotivasi dan antusias dalam menerima pembelajaran yang diajarkan. Pendidik dituntut untuk memberikan pembelajaran yang menyenangkan kepada anak dan memberikan kesempatan kepada anak untuk mengeluarkan apa yang dirasakan dan apa yang dipikirkan.

Pendidik dapat membantu mendorong perkembangan bahasa anak yang alami dengan menyediakan lingkungan yang penuh dengan kesempatan mengembangkan bahasa. Menurut Suyanto dalam Susanto, melatih anak belajar bahasa dapat dilakukan dengan cara berkomunikasi melalui berbagai Setting, yaitu kegiatan bermain bersama, bercerita, bermain peran, bermain puppet dan boneka tangan, dan belajar dan bermain dalam kelompok. Cara-cara dalam melatih bahasa anak yang dikatakan oleh Suyanto dapat melatih anak dalam mengembangkan perkembangan bicaranya.

Berdasarkan hasil observasi yang telah dilakukan, yang terjadi di lapangan khususnya di PAUD Tunas, kemampuan bicara anak masih belum sesuai dengan tahapan perkembangan bicaranya. Peneliti meminta anak untuk menggambar bebas dan meminta anak untuk menceritakan hasil gambar yang dibuat. Ketika peneliti meminta masing-masing anak untuk menceritakan hasil gambar yang dibuat, anak-anak kurang lancar dalam menceritakan gambar yang dibuat sehingga memerlukan bantuan dari peneliti. Anak juga bercerita dengan wajah yang datar. Anak-anak pada PAUD Tunas juga kurang dapat mengeluarkan apa yang dipikirkan. Ketika bercerita, peneliti harus memberikan pertanyaan terlebih dahulu mengenai apa yang digambar anak, setelah itu anak baru mengeluarkan suaranya.

Dalam pengamatan, anak-anak akan mengeluarkan suara yang keras ketika bersama-sama, tetapi suara yang dikeluarkan pelan ketika berbicara sendiri. Berdasarkan hasil wawancara dengan guru, guru pada PAUD Tunas juga mengakui anak di PAUD Tunas hanya bersuara keras ketika bersama-sama, tetapi pelan ketika berbicara sendiri. Berdasarkan observasi, ketika jam istirahat, ada seorang anak yang bercerita mengenai pengalaman pergi bersama keluarga kepada peneliti tetapi anak tersebut kurang jelas dalam menceritakan pengalamannya.

Peneliti melakukan tanya jawab dengan masing-masing anak di PAUD Tunas. Berdasarkan hasil observasi, setelah melihat karakteristik kemampuan berbicara anak usia 4-5 tahun, terdapat sepuluh anak yang masih kurang berkembang dalam kemampuan berbicaranya. Ada anak yang masih terbata-bata dalam mengucapkan sesuatu 
dan kurang jelas dalam menyampaikan sesuatu, seperti "tadi kemarin aku pulang kampung".

Berdasarkan hasil pengamatan, kemampuan berbicara yang kurang berkembang disebabkan karena kurangnya stimulus yang diberikan oleh guru dalam kemampuan berbicara anak pada kegiatan pembelajaran.Kegiatan pembelajaran yang diberikan di PAUD Tunas lebih banyak kegiatan mewarnai dan menebalkan huruf. Guru tidak memberikan kegiatan yang dapat meningkatkan kemampuan berbicara anak. Guru kurang memberikan kesempatan dan motivasi bagi anak untuk berbicara. Interaksi antara sesama anak didik kurang terlihat karena guru lebih banyak memberikan kegiatan yang bersifat individu.

Berdasarkan uraian sebelumnya, maka untuk mengatasi masalah tersebut perlu adanya kegiatan yang dapat mengembangkan kemampuan berbicara anak. Banyak cara yang dapat dilakukan oleh pendidik dalam melatih perkembangan bicara anak. Circle time merupakan salah satu cara yang dapat digunakan untuk melatih perkembangan bicara anak. Circle time merupakan kegiatan di dalam kelas yang efektif untuk mengembangkan kemampuan berbicara dan mendengarkan anak. Circle time dapat diartikan sebagai kegiatan berkumpul bersama dalam satu karpet yang dapat menstimulasi kemampuan berbicara dan mendengarkan. Ketika kegiatan circle time, anak saling melihat satu sama lain, sehingga akan memudahkan anak dalam berkomunikasi satu sama lain.

Ketika circle time, anak akan saling berinteraksi dan saling berbagi. The circle is a symbol of unity and co-operation. It indicates that the group is working together to support one another. Lingkaran adalah simbol persatuan dan kerjasama. Hal ini menunjukkan bahwa kelompok ini bekerja sama untuk saling mendukung satu sama lain. Kegiatan Circle time pada penelitian ini adalah kegiatan dimana anak duduk melingkar di dalam kelas. Pada keadaan duduk melingkar, anak dapat saling menatap satu sama lain dan lebih mudah berinteraksi satu sama lain. Kegiatan circle time ini dilakukan kapan saja yaitu pada saat pembukaan, inti, ataupun penutup.

Dalam kegiatan circle time, anak diminta untuk mengeluarkan apa yang ada dipikirannya.Banyak kegiatan yang dapat dilakukan pada circle time. Salah satu contoh kegiatan pada circle time yaitu games, guru meminta anak untuk mengatakan apa yang dipikirkan anak ketika guru menyebutkan suatu kata atau meminta anak untuk melanjutkan kalimat yang diberikan oleh guru. Circle time ini, dilakukan selama 10-15 menit. Sebelum melakukan circle time, guru memberikan 
peraturan kepada anak agar anak mendengarkan ketika temannya berbicara dan memberikan reward kepada anak yang sudah mengeluarkan apa yang dipikirkan.

Kegiatan circle time dapat meningkatkan kemampuan berbicara anak. Hal tersebut didukung dengan jurnal yang berjudul Aktualisasi Kecerdasan Verbal Linguistik Anak Usia Dini Melalui Pendekatan Beyond Centers and Circle Time $(B B C T)$ di TK ABA NUR'AINI Ngampilan, Yogyakarta. Berdasarkan jurnal tersebut, peneliti dapat menggunakan kegiatan circle time dalam penelitian tindakan yang akan dilakukan.

Melalui penelitian ini diharapkan dapat meningkatkan kemampuan berbicara anak di PAUD Tunas dan dapat memperoleh nuansa baru bagi anak didik. Penelitian yang dilakukan diharapkan dapat memberikan pembelajaran yang menyenangkan untuk anak dan dapat memberikan strategi mengajar bagi guruguru di PAUD Tunas. Perlunya penelitian tindakan kelas ini untuk meningkatkan kemampuan berbicara anak dengan menggunakan kegiatan circle time.

\section{KAJIAN TEORITIK}

Setiap individu pada dasarnya memiliki kemampuan dalam berbicara. Sebelum seseorang berbicara, maka terlebih dahulu harus memiliki kemampuan mendengar atau menyimak. Seperti yang dikemukakan oleh Jalongo, "of all the language skills that human beings acquire, listening is the one they will use earliest”. Kemampuan mendengar atau menyimak adalah kemampuan bahasa yang paling awal dimiliki oleh manusia. Kemampuan menyimak atau mendengar akan mempengaruhi kemampuan berbicara anak, seperti halnya yang dikemukakan oleh Tarigan bahwa, ujaran (speech) biasanya dipelajari melalui menyimak dan meniru (imitasi). Ketika anak telah dapat menyimak dengan baik, maka anak-anak akan memperoleh kosakata dan kecakapan dalam berbicara.

Setelah anak dapat menyimak apa yang dikatakan orang lain, maka kemampuan berbicara anak akan berkembang dengan baik. Kemampuan berbicara merupakan kemampuan untuk mengungkapkan kata-kata dan akan berkembang dengan baik jika terus dilatih. Menurut Soemiarti, kemampuan bicara terdiri dari ungkapan dalam bentuk katakata. Kemampuan bicara merupakan ungkapan yang dikatakan seseorang untuk mengeluarkan pendapat atau mengekspresikan perasaan melalui katakata. Kemampuan bicara digunakan dalam kehidupan sehari-hari untuk melakukan komunikasi dengan orang lain.

Ketika berkomunikasi, berarti seorang mengeluarkan bunyi yang digunakan untuk menyampaikan suatu pesan.Menurut Arsyad bahwa kemampuan 
berbicara adalah kemampuan mengucapkan bunyi-bunyi artikulasi atau mengucapkan kata-kata untuk mengekspresikan, menyatakan, menyampaikan pikiran, gagasan dan perasaan. Dalam berbicara maka seseorang akan menggunakan mulutnya sehingga dapat mengungkapkan apa yang dipikirkan. Seperti halnya yang diungkapkan oleh Dyer, kemampuan bicara terdiri dari berbagai bunyi yang dibuat orang dengan mulut untuk menyampaikan suatu pesan; hal tersebut merupakan sarana yang digunakan untuk berkomunikasi. Berbicara digunakan sebagai sarana berkomunikasi dengan orang lain.

Memiliki kemampuan bicara yang baik, akan memudahkan dalam berkomunikasi dengan orang lain. Seperti halnya yang dikemukakan oleh William dan Johnson, bahwa speech or oral communication is the basic tools by which an individual relates to others in the world around him. Pendapat tersebut dapat diartikan, kemampuan berbicara atau komunikasi langsung adalah alat dasar dimana seorang individu berhubungan dengan orang lain di sekeliling. Berdasarkan pendapat sebelumnya, maka sangat penting memiliki kemampuan berbicara karena dapat mempengaruhi kehidupan sosial.
Ketika seorang memiliki kemampuan berbicara yang tidak baik, maka hubungan sosialnya tidak akan baik begitu pula sebaliknya. Speech is defective when it is ungrammatical, unintelligible, culturally or personally, unsatisfactory, or abusive of the speech mechanism. Pendapat sebelumnya dapat diartikan bahwa, kemampuan berbicara dapat kurang sempurna ketika tata bahasanya tidak benar, tidak dapat dimengerti, berhubungan dengan kebudayaan atau diri sendiri, tidak memuaskan, atau menghina. Berdasarkan pendapat tersebut maka, perlu adanya kehati-hatian dan kejelasan dalam hal berbicara dengan orang lain agar dapat dimengerti dan juga agar tidak merusak hubungan sosial dengan orang lain di sekitar. Speech is such a natural part of our everyday that we seldom stop to consider its importance the ways it help us and the ways it sometimes fails us. Pernyataan tersebut dapat diartikan bahwa kemampuan berbicara merupakan suatu bagian yang alami dari keseharian yang dapat menolong dan terkadang menjatuhkan. Perlunya memikirkan terlebih dahulu apa yang akan dibicarakan dan memperhatikan indikator dari kemampuan berbicara agar apa yang dibicarakan tidak menjatuhkan diri sendiri.

Kemampuan berbicara dengan orang lain perlu dilatih dan perlu memperhatikan beberapa aspek dari kemampuan berbicara. 
Safari mengemukakan bahwa terdapat dua aspek yang harus diperhatikan, yaitu:

Pertama, aspek kebahasaan yang terdiri dari: ketepatan pengucapan/pelafalan (vokal, konsonan, intonasi dan tekanan), ketepatan penempatan tekanan kata/ ungkapan, ketepatan penggunaan (nada, irama, pemilihan kata, ungkapan, istilah, variasi kata, kata bentukan, struktur kalimat dan majas). Kedua, aspek non kebahasaan (aspek pengungkapan dan aspek penampilan) yang diantaranya: kelancaran (tidak banyak mengulang kata-kata yang sama), mimik, menyampaikan/berbicara, keberanian dan semangat dan kenyaringan suara.

Ketika berbicara, perlu memperhatikan ketepatan ucapan agar orang lain mengerti apa yang dikatakan. Penempatan tekanan dan nada juga perlu diperhatikan, misalnya ketika bertanya tekanan dan nadanya akan berbeda dengan hanya memberikan pernyataan. Pilihan kata dan pemakaian kalimat harus disesuaikan dengan apa yang akan dibicarakan dengan lawan bicara. Berbicara dengan orang lain juga perlu memperhatikan sikap, pandangan mata, gerak-gerik, mimik, volume, kelancaran, dan penguasaan dari apa yang dibicarakan, serta keberanian dan kenyaringan suara. Ketika berbicara dengan orang lain, maka bukan hanya suara yang didengar tapi cara menyampaikan juga dilihat.

Berdasarkan pendapat-pendapat sebelumnya, maka kemampuan berbicara dapat diartikan kesanggupan seseorang untuk berkomunikasi dengan orang lain dengan menggunakan tata bahasa yang baik untuk mengekspresikan, menyatakan, menyampaikan pikiran, gagasan dan perasaan yang dapat menolong dan dapat pula menjatuhkan. Kemampuan bicara juga dipengaruhi oleh beberapa faktor yaitu ketepatan ucapan, penempatan tekanan dan nada, pilihan kata, pemakaian kalimat, sikap yang wajar, pandangan mata, gerak-gerik dan mimik yang tepat, volume suara, kelancaran, dan penguasaan topik.

\section{TUJUAN KEMAMPUAN BERBICARA}

Berbicara berarti mengungkapkan apa yang dipikirkan. Dengan berbicara, maka seorang akan mengetahui apa saja yang sebelumnya tidak diketahui. Menurut Sonawat dan Francis, tujuan berbicara adalah to make wants and needs known, for expressions of emotions, device for gaining information, to social interaction, and aid to personal identification. Berbicara bertujuan agar orang lain mengetahui apa yang diinginkan dan apa yang dibutuhkan. Berbicara juga dapat mengekspresikan emosi kepada orang lain. Anak dapat mengekspresikan perasaan marah, senang, sedih kepada orang lain. 
Berbicara juga digunakan untuk menambah informasi.Anak dapat bertanya dengan orang yang lebih dewasa untuk mengetahui informasi yang ingin diketahui. Berbicara digunakan untuk interaksi sosial yaitu untuk berkomunikasi dengan orang lain. Berbicara juga digunakan untuk membantu mengidentifikasi diri sendiri. Anak dapat memperkenalkan diri kepada orang lain melalui berbicara.

Berbicara merupakan alat untuk berkomunikasi dengan orang lain. Hal yang ingin dicapai dari berbicara adalah untuk mengungkapkan apa yang dipikirkan dan apa yang dirasa. Speech used in communication between human. Pendapat sebelumnya dapat diartikan bahwa, kemampuan berbicara digunakan dalam komunikasi antar sesama manusia. Dalam berkomunikasi, maka seorang dapat berbicara mengenai apa yang telah diketahui dan dapat membentuk makna dari pengetahuan baru yang diperoleh.

\section{Berbicara} membutuhkan kemampuan berpikir untuk menyampaikan sesuatu kepada orang lain. Yusuf berpendapat, berbicara digunakan untuk mengembangkan kemampuan berpikir dan mengembangkan kemampuan penyesuaian sosial. Berbicara digunakan untuk mengembangkan kemampuan berpikir anak dalam membentuk pengertian, menyusun pendapat, dan menarik kesimpulan dari apa yang diketahui. Berbicara juga digunakan untuk mengembangkan kemampuan penyesuaian sosial karena dengan berbicara, maka anak dapat berkomunikasi dengan orang lain dan dapat menyesuaikan diri dengan lingkungannya. Selain itu, menurut Herrick dan Jacobs yang ingin dicapai dari kemampuan bicara adalah:

(1) prizing thingking and feeling,

(2) valuing effectiveness, (3)

aiming for acceptability, (4) increasing poise and assurance, (5) developing word sensitivess, (6) improving voice qualities, (7) extending language courtesies.

Pendapat sebelumnya dapat diartikan yaitu: pertama, menghargai pemikiran dan perasaan. Anak menggunakan berbicara untuk mengkomunikasikan ide, opini, meyakinkan, menilai, mengungkapkan apa yang terjadi, dan bercerita. Anak juga belajar untuk mengekspresikan perasaan gembira, kecewa, meminta pertolongan, marah, rasa puas, dan rasa sayang.

Tujuan kedua yaitu menilai keefektifan. Efektif tidaknya apa yang dibicarakan tergantung dari ada tidaknya orang yang mau mendengarkan karena orang berbicara membutuhkan minimal satu pendengar. Ketiga, tujuan untuk penerimaan yaitu anak akan belajar bahwa terdapat konsekuensi dari apa yang 
dibicarakan. Anak mulai belajar agar orang lain menerima apa yang dibicarakan atau mengerti apa yang dimaksud. Keempat, meningkatkan ketenangan yaitu ketika anak mampu berbicara dengan natural dan dapat mengontrol diri dalam percakapan, diskusi, dan melaporkan sesuatu. Anak akan merasa nyaman untuk berbicara ketika lingkungan sekitar mendukung anak untuk berbicara.

Kelima, mengembangkan kata sensitif yaitu ketika anak mengekspresikan perasaan dan anak akan membutuhkan kosakata yang banyak untuk mengungkapkan pendapat kepada orang lain. Keenam, meningkatkan kualitas suara, yaitu ketika anak mendapat respon yang menyenangkan dari orang lain maka suara yang dikeluarkan akan lebih baik lagi. Tujuan ketujuh, memperluas sapa bahasa. Ketika berbicara, intonasi suara, kata yang dipilih, bahasa tubuh, dan ekspresi wajah akan terlihat, maka anak akan belajar mengenai hal tersebut agar diterima oleh pendengar.

Berdasarkan pendapat-pendapat sebelumnya, maka tujuan dari berbicara adalah agar orang lain mengetahui apa yang diinginkan dan apa yang dibutuhkan, untuk mengekspresikan emosi atau perasaan, untuk menambah informasi, untuk interaksi sosial, untuk mengidentifikasi diri sendiri, untuk mengembangkan kemampuan berpikir dan mengembangkan kemampuan penyesuaian sosial, untuk menghargai pemikiran dan perasaan, untuk menilai keefektifan, untuk penerimaan, untuk meningkatkan ketenangan, untuk mengembangkan kata sensitif, dan untuk memperluas sapa bahasa.

\section{FAKTOR YANG MEMPENGARUHI KEMAMPUAN BERBICARA}

Kemampuan berbicara dapat dipengaruhi oleh banyak faktor. Jalongo berpendapat bahwa faktor yang mepengaruhi perkembangan bicara ada tiga, yaitu:

(1) Neurological Factors (cognitive development, information processing strategies, motor output capabilities, socioemotional development and motivation), (2) Structural and Physiological Factors (sensory acuity, oromuscular capabilities, speech transmission mechanisms),

Environment Factors

(sociocultural variables, experiences, physical context).

Pendapat sebelumnya dapat diartikan bahwa faktor yang mempengaruhi perkembangan bicara adalah pertama, faktor saraf. Faktor saraf ini dapat berupa perkembangan kognitif yang dimiliki anak. Proses informasi yaitu anak akan belajar bagaimana memperhatikan dengan fokus untuk membedakan antara suara yang 
diucapkan dan memasukkan ke dalam memori. Kapabilitas dalam mengeluarkan kata yaitu gerakan antara bibir dan lidah untuk mengeluarkan suara.Perkembangan sosial emosional karena berbicara merupakan interaksi antar manusia dan dapat memotivasi.

Kedua adalah faktor struktur dan fisik.Faktor ini meliputi ketajaman sensori anak memahami pengertian dari yang dibicarakan.Anak tidak hanya mendengar, tapi dapat berbicara. Kemampuan oromuscular yaitu kemampuan pada otot kerongkongan yang mengontrol bibir dan lidah.Faktor ini berhubungan dengan kondisi kesehatan dan alat transmisi untuk berbicara yaitu berhubungan dengan kemampuan pernapasan.

Ketiga adalah faktor lingkungan. Faktor lingkungan meliputi sosial budaya yaitu orang-orang yang berada di sekitar anak dan cara berbicara yang dicontohkan kepada anak. Pengalaman, karena berbicara dipengaruhi oleh respon dari pengasuh dan kesempatan interaksi verbal dan nonverbal anak. Benda di sekitar, benda yang berada di sekitar dapat memancing anak untuk berbicara.Mainan, buku, dan benda lainnya dapat menstimulasi anak untuk bercakap-cakap.

Selain faktor saraf, struktur dan fisik, serta faktor lingkungan, pendapat lain menyebutkan bahwa faktor yang mempengaruhi perkembangan berbicara adalah (1) Kecerdasan, (2) Jenis Kelamin, (3) Kondisi Fisik, (4) Lingkungan Keluarga, (5) Kondisi Ekonomi, (6) Setting Sosial/Lingkungan-Budaya, (7) Bilingualism. Pertama, kecerdasan dapat mempengaruhi kemampuan berbicara karena kemampuan berbicara dapat diukur melalui intelegensi yang dimiliki. Seseorang yang memiliki kecerdasan yang baik, biasanya memiliki kemampuan berbicara yang baik pula. Bicara merupakan alat bantu dalam belajar, maka jika seseorang yang kurang dalam kemampuan bicara, maka akan mempengaruhi belajarnya. Walaupun biasanya kecerdasan yang baik dapat dilihat dari kemampuan bicaranya, tapi tidak menutup kemungkinan bahwa orang yang memiliki kecerdasan kurang tidak memiliki kemampuan bicara yang baik karena kemampuan bicara dapat juga diperoleh melalui latihan secara terus menerus.

Kedua, jenis kelamin dapat mempengaruhi perkembangan bicara karena biasanya anak perempuan lebih baik dan cepat dalam kemampuan bicara. Hal ini disebabkan karena lingkungan bermain anak perempuan yang sering menggunakan bahasa verbal, seperti bermain boneka, sedangkan anak laki-laki lebih banyak pada kegiatan motorik. Ketiga, kondisi fisik dapat mempengaruhi kemampuan bicara karena jika terdapat 
masalah pada fisik anak terutama pada organ bicara seperti gigi, lidah, bibir, tenggorokan, dan pita suara dan pada organ pendengaran, maka kemampuan bicara tidak akan berkembang dengan baik. Organ bicara dan pendengaran merupakan alat yang digunakan untuk berkomunikasi.

Keempat, lingkungan keluarga merupakan faktor yang mempengaruhi perkembangan bicara anak karena lingkungan keluarga merupakan lingkungan yang paling dekat dengan anak dan anak lebih banyak menghabiskan waktu di lingkungan keluarga. Orang tua yang memberi dorongan kepada anak dengan sering mengajak anak berbicara, akan membuat anak lebih cepat dalam perkembangan bicaranya. Orang tua yang memilik anak yang banyak akan lebih sulit untuk membantu perkembangan bicara anak, lain halnya dengan orang tua yang memiliki anak sedikit. Kelima, kondisi ekonomi dapat mempengaruhi kemampuan bicara karena orang-orang yang berasal dari kelas atas, lebih memiliki kemampuan bicara yang baik dibandingkan dengan orang yang berasal dari kelas bawah. Biasanya orang yang berasal dari kelas atas, mendapatkan pendidikan yang lebih baik sehingga kemampuan bicaranya juga baik.

Keenam, Setting sosial/Lingkungan budaya mempengaruhi perkembangan bicara anak karena anak dari daerah lebih sering mendengar bahasa daerah maka akan kesulitan dalam berbicara dengan lingkungan yang menggunakan Bahasa Indonesia. Anak yang tidak dapat menyesuaikan diri dengan lingkungan yang berBahasa Indonesia maka akan mengalami keterlambatan dalam berbicara karena tidak adanya interaksi dengan orang lain. Ketujuh, bilingualism dapat mempengaruhi perkembangan bicara anak karena anak yang telah diajari dua bahasa oleh orang tua akan mengalami kesulitan dalam pengucapan dan penguasaan kata. Anak akan mengalami kebingungan dalam mengeluarkan kata.

Selain faktor sebelumnya, terdapat faktor lain yang dapat mempengaruhi kemampuan berbicara. Menurut Arsyad, keefektifan berbicara juga dapat dipengaruhi oleh beberapa faktor yaitu, lafal atau ucapan dan pola-pola intonasi serta tekanan, penguasaan tata bahasa, kosa kata, kelancaran dan kefasihan dan pemahaman. Faktor-faktor tersebut sangat mempengaruhi kemampuan berbicara seseorang karena dapat menentukan paham atau tidaknya lawan bicara.

Berdasarkan pendapat-pendapat sebelumnya, faktor yang mempengaruhi perkembangan bicara ada dua yaitu faktor dalam diri dan faktor dari luar. Faktor dalam diri meliputi: faktor saraf yang digunakan untuk memprosesan kata-kata 
yang di dalamnya terdapat juga faktor kecerdasan, serta lafal atau ucapan dan pola-pola intonasi serta tekanan, penguasaan tata bahasa, kosa kata, kelancaran dan kefasihan dan pemahaman, faktor fisik yaitu bagaimana kata-kata itu keluar dan juga jenis kelamin. Faktor dari luar meliputi: faktor lingkungan sekitar yaitu keluarga, sekolah, masyarakat, dan sosial budaya.

\section{KARAKTERISTIK PERKEMBANGAN BICARA ANAK USIA 4-5 TAHUN}

Anak pada usia 4-5 tahun mengalami perkembangan berbicara yang cepat karena masa-masa ini merupakan masa emas anak. Anak usia 4-5 tahun sudah mulai menggunakan kata depan, seperti "di bawah", “di atas", “di samping". Anak sudah mulai dapat menggunakan kata "di sini", "di sana", “jarang”, kadang-kadang”, dan anak sudah dapat menggunakan kata benda dan kata kerja sebagaimana mestinya.

Kalimat anak juga sudah terdiri dari 4-5 kata dan sudah dapat menggunakan kalimat negatif serta menyusun pertanyaan dengan benar.Menurut Mussen dkk dalam Christiana, pada masa-masa 4-5 tahun pembicaraan anak lebih lama dan kompleks, dapat mengatakan dua ide dalam satu kalimat, kata-kata saling berhubungan, serta lebih menyerupai orang dewasa. Anak usia 4-5 tahun mampu untuk merangkai suatu huruf menjadi kata, dan kata menjadi sebuah kalimat, serta dapat memainkan suatu peran orang dewasa. Pada usia ini, anak juga sudah dapat mengetahui hubungan sebab akibat (seperti: saya makan karena lapar). Jalongo berpendapat bahwa:

4 years vocabulary: 1.400 to 1.600 word. Social: child seeks ways to correct misunderstandings; begin to adjust speech to listener's information needs; disputes with peers can be resolved with words and invitations to play are more common. 5 year vocabulary: uses approaximately 2.500 words, understands about 6.000, respons to 25.000. Social: child has good control of elements of conversation.

Anak usia 4 tahun memiliki kosa kata 1.400 sampai 1.600 kata dan dalam sosialnya, anak dapat mengoreksi apa yang tidak jelas, dimulai dari hanya berbicara untuk pendengar yang membutuhkan informasi; bertengkar dengan teman dan dapat memecahkannya dengan kata atau undangan untuk bermain kembali seperti biasa. Anak usia 5 tahun memiliki kosa kata mencapai 2.500 kata, mengerti 6.000 kata, dan dapat menanggapi sampai 25.000 kata. Sosial anak usia 5 tahun adalah anak 
telah dapat mengontrol dengan baik bagian dari percakapan.

Berdasarkan pendapat-pendapat sebelumya, maka dapat dilihat bahwa anak usia 4-5 tahun telah memiliki banyak kosakata. Anak akan berbicara dengan lebih lama dan kompleks. Anak usia 4-5 juga telah memiliki kemampuan untuk bercakap-cakap dengan susunan kalimat yang lebih baik.

Anak usia 4-5 tahun perlu diberikan stimulasi agar perkembangan bicara yang dimilliki dapat lebih berkembang. Berbagai cara dapat dilakukan untuk mengembangkan kemampuan berbicara. Menurut Bromley, terdapat beberapa cara yang dapat dilakukan untuk mengembangkan kemampuan bicara anak, yaitu: (1) Conversation, (2) Discussion, (3) Report, (4) Creative Dramatic, (5) Storytelling. Bercakap-cakap dapat mengembangkan kemampuan bicara anak.Ketika anak bercakap-cakap bersama, anak belajar untuk memulai dan mengakhiri percakapan, menjaga perhatian kepada pendengar, dan mengklarifikasi untuk berbicara.Kemampuan untuk bercakapcakap dapat didapat melalui aktivitas telepon dan interview. Berdiskusi merupakan bentuk formal dari bercakapcakap.Berdiskusi berarti membicarakan suatu topik bersama-sama dalam kelompok. Brainstorming merupakan salah satu bentuk dari diskusi.

Laporan merupakan presentasi dari informasi yang didapat kepada kelompok. Memberikan laporan dimulai dengan anak berbicara di depan kelompok lalu menyampaikan laporan yang didapat. Bentuk dari laporan adalah share and tell dan newstime. Drama kreatif merupakan persembahan anak untuk mengungkapkan perasaan melalui tindakan pada situasi, adegan, atau permainan. Anak dapat memainkan peran untuk menjadi orang lain. Bentuk dari drama kreatif yaitu puppet.

Bercerita merupakan menceritakan langsung apa yang terjadi atau bercerita dengan menggunakan buku cerita. Bercerita menstimulasi imajinasi anak, inspirasi, dan membangun rasa humor anak.bercerita memberikan kesempatan kepada anak untuk berbicara dengan bahasa formal atau bahasa tidak formal. Bercerita membangun kosakata anak, menambah pemahaman, dan membantu perkembangan sosial, dan emosional anak. Pendapat sebelumnya sejalan dengan pendapat Herrick dan Jacobs, cara yang dapat dilakukan untuk mengembangkan kemampuan berbicara anak adalah: (1)

Conversation, (2) Discussion, (3)

Telephoning, (4) Storytelling, (5)

Reporting, (6) Interviewing,

Intruduction. Cara untuk mengembangkan 
kemampuan berbicara tersebut yaitu melakukan percakapan, melakukan diskusi, bertelepon, bercerita, melaporkan laporan, melakukan wawancara, dan memperkenalkan diri.

Terdapat cara lain yang dapat dilakukan untuk mengembangkan kemampuan berbicara. Menurut Vukelich, Christie, and Enz, terdapat beberapa cara yang dapat dilakukan, yaitu: (1) Group Activities, (2) Learning Centers, (3) Dramatic Play, (4) Sharing, (5) Storytelling, (6) Language Play, (7) Songs and Finger Plays. Pada aktivitas kelompok, guru menganjurkan dan mengharuskan anak untuk berinteraksi secara langsung. Pusat belajar yaitu guru menyediakan berbagai sentra dalam belajar. Bermain drama yaitu anak memainkan peran menjadi orang lain. Berbagi yaitu strategi untuk mengembangkan kemampuan berbicara dan mendengarkan.Anak berbagi mengenai pengalaman yang dialami. Bercerita dapat menyambungkan antara yang bercerita dengan pendengar untuk bersantai mendengarkan cerita dan membuat pendengar aktif dalam menanggapi cerita.

Permainan bahasa merupakan permainan yang dilakukan untuk mengembangkan bahasa anak. Dalam permainan bahasa ini, guru dan anak dapat bermain kata, membuat lelucon, dan berbagai permainan lainnya.Often we hear children play with language, using language as a toy. In example, using the y suffix to express a change from noun to adjective. Ketika mendengar anak bermain dengan bahasa, gunakan bahasa sebagai alat bermain.Contohnya, gunakan akhiran -y untuk memperlihatkan perubahan dari kata benda ke kata sifat. Misalnya, "cause it's fishy too. Cause it has fishes". Kata bendanya adalah fishes yang berarti ikan dan dirubah menjadi kata sifat yaitu fishy yang berarti amis. Lagu dan bermain jari yaitu guru dapat bernyayi dengan menggunakan jari yang dapat menambah kosakata anak dan anak dapat bernyanyi bersama-sama guru. Misalnya guru dan murid dapat bernyanyi "mana jempol" bersama-sama.

Selain cara yang telah disebutkan sebelumnya, terdapat cara lain yang dapat digunakan orang dewasa dalam mengembangkan kemampuan berbicara anak, yaitu: Recasting, Expanding, and Labeling. Recasting adalah menyusun kembali. Orang dewasa dapat meningkatkan apa yang dikatakan anak dengan cara lain, bisa dengan mengajukan pertanyaan kepada anak atau mengulangi ucapan anak yang belum lengkap. Contohnya ketika anak berkata “telepoberbunyi”, orang dewasa dapat merespon dengan memberikaan pertanyaan "kapan telepon berbunyi?". 
Expanding adalah mengembangkan. Orang dewasa dapat mengulangi kata yang diucapkan anak dengan kata yang lebih lengkap. Contohnya ketika anak berkata "kakak makan", orang dewasa dapaat menanggapi dengan berkata "ya, kakak sedang makan sekarang".Labeling adalah pemberian nama. Orang dewasa dapat memperkenalkan nama dari objek yang ada. Anak akan terus bertanya mengenai nama dari objek yang dilihat. Cara ini dapat meningkatkan kosakata anak. Semua cara yang disebutkan dapat digunakan oleh orang tua untuk meningkatkan kemampuan berbicara anak. Parents use these strategies naturally and in meaningful conversation. Parents don't use any deliberate method to teach their children to talk. Orang tua dapat menggunakan strategi yang alami dalam percakapan yang bermakna. Orang tua tidak boleh menggunakan cara yang disengaja untuk mengajari anak berbicara. Cara yang disengaja dapat memperlambat anak untuk belajar berbicara.

Berdasarkan pendapat sebelumnya, maka cara yang dapat ditempuh untuk mengembangkan kemampuan bicara anak yaitu: percakapan, diskusi, laporan, drama kreatif, bercerita, aktivitas dalam kelompok, pusat belajar, berbagi, permainan bahasa, dan lagu dan permainan jari. Cara yang dikatakan sebelumnya dapat dilakukan guru di sekolah. Cara untuk mengembangkan kemampuan berbicara anak yang dapat dilakukan oleh orang tua di rumah yaitu: menyusun kembali kata yang diucapkan anak dengan memberikan pertanyaan atau mengulangi perkataan anak yang belum lengkap, mengembangkan apa yang dikatakan anak, dan memberi nama pada objek yang anak tanyakan.

\section{METODOLOGI PENELITIAN}

Metode penelitian yang digunakan adalah penelitian tindakan kelas.Menurut Arikunto dalam Suyadi, penelitian tindakan kelas (PTK) adalah pencermatan dalam bentuk tindakan terhadap kegiatan belajar yang sengaja dimunculkan dan terjadi dalam sebuah kelas secara bersamaan. Penelitian ini dilakukan dengan memberikan tindakan yang sengaja dibuat untuk dilakukan di dalam kelas.

Desain intervensi tindakan/rancangan penelitian ini menggunakan model Kemmis dan Taggart. Prosedur tindakan yang dikemukakan Kemmis dan Taggart, meliputi: (1) Plan (perencanaan), (2) Act (tindakan), (3) Observe (pengamatan), (4) Reflect (refleksi) untuk siklus pertama, kemudian dilanjutkan dengan siklus kedua yaitu dimulai dengan Revised Plan (memperbaiki perencanaan), Act (tindakan), Observe (pengamatan), Reflect 
(refleksi), begitu seterusnya untuk tiap siklus yang dilakukan. Subjek dalam penelitian ini adalah anak-anak yang berada di PAUD Tunas yang memiliki rentang usia 4-5 tahun. Subjek dalam penelitian berjumlah sepuluh anak.Pemilihan subjek penelitian ini dilakukan pada pra penelitian yang dilakukan melalui kegiatan observasi dan wawancara dengan guru kelas yang teridentifikasi kemampuan berbicaranya masih rendah.

Partisipan yang terlibat dalam penelitian ini adalah peneliti sendiri yang berperan sebagai pelaksana tindakan dan pengamat. Peneliti juga melibatkan kolaborator yaitu guru pada PAUD Tunas yang akan berperan sebagai partisipan dan pengamat.

\section{HASIL DAN PEMBAHASAN}

Data penelitian menunjukkan hasil tindakan penerapan kegiatan circle time pada siklus I mencapai rata-rata presentase sebesar $51 \%$ dan pada siklus II $76 \%$. Peningkatan siklus I ke sikus dua mencapai 25\%. Hal tersebut berarti telah mencapai peningkatan indikator keberhasilan yang telah ditetapkan antara peneliti dan kolaborator yaitu peningkatan sebesar $20 \%$. Berdasarkan hasil analisa dapat diinterpretasikan pada tabel 16 sebagai berikut:
Hasil Interpretasi Data

\begin{tabular}{|c|c|c|c|}
\hline No & Siklus & Presentase & $\begin{array}{l}\text { Interpretasi } \\
\text { Hasil Analisis }\end{array}$ \\
\hline 1 & $\begin{array}{l}\text { Pra } \\
\text { Penelitian }\end{array}$ & $39 \%$ & $\begin{array}{l}\text { Hasil rata-rata } \\
\text { kemampuan } \\
\text { berbicara anak } \\
\text { termasuk } \\
\text { dalam kriteria } \\
\text { kemampuan } \\
\text { berbicara } \\
\text { rendah }\end{array}$ \\
\hline 2 & Siklus I & $51 \%$ & $\begin{array}{l}\text { Hasil rata-rata } \\
\text { kemampuan } \\
\text { berbicara anak } \\
\text { termasuk } \\
\text { dalam kriteria } \\
\text { kemampuan } \\
\text { berbicara } \\
\text { rendah }\end{array}$ \\
\hline 3 & Siklus II & $76 \%$ & $\begin{array}{l}\text { Hasil rata-rata } \\
\text { kemampuan } \\
\text { berbicara anak } \\
\text { termasuk } \\
\text { dalam kriteria } \\
\text { kemampuan } \\
\text { berbicara } \\
\text { tinggi }\end{array}$ \\
\hline
\end{tabular}

Mengacu pada data interpretasi hasil analisis telah terjadi adanya peningkatan pada kemampuan berbicara anak setelah menerapkan kegiatan circle time. Berdasarkan hasil presentase yang didapat pada akhir siklus II maka peneliti dan kolaborator merasa telah ada ketercapaian yang dirasa cukup, sehingga peneliti dan kolaborator memutuskan untuk menghentikan penelitian pada akhir siklus II. Dengan demikian hipotesis tindakan yang menyatakan bahwa penggunaan penerapan kegiatan circle time dapat meningkatkan kemampuan berbicara anak usia 4-5 tahun dapat diterima. Tindakan yang dapat dilakukan selanjutnya yaitu penerapan kegiatan circle 
time harus tetap dilakukan agar kemampuan berbicara anak dapat terus berkembang secara optimal.

\section{HASIL PENELITIAN DAN PEMBAHASAN}

Pada presentase hasil tindakan siklus I dan II mengalami peningkatan sebanyak $25 \%$. Hal tersebut telah mencapai indikator keberhasilan yang ditetapkan peneliti dan kolaborator yaitu peningkatan sebesar $20 \%$ dari siklus I ke siklus II. Hal tersebut dapat menunjukkan kesesuaian dengan hipotesis yang diterima. Dengan demikian dapat dinyatakan bahwa penerapan kegiatan circle time dapat meningkatkan kemampuan berbicara anak usia 4-5 tahun.

Hasil analisis data kualitatif yang dilakukan dengan mengacu kepada hasil pengamatan dan catatan lapangan membuktikan bahwa penerapan kegiatan circle time dapat membantu meningkatkan kemampuan berbicara anak. Pada penelitian ini, pemberian kegiatan circle time dapat melatih anak untuk berbicara. Hal tersebut sesuai dengan pernyataan Grugeon yang menyatakan bahwa circle timedapat menstimulasi kemampuan berbicara dan mendengarkan anak. Berdasarkan pernyataan tersebut, maka kegiatan circle time mampu meningkatkan kemampuan berbicara anak dengan memberikan kesempatan kepada anak untuk berbicara
Kegiatan-kegiatan yang dilakukan pada circle time merupakan kegiatan yang dapat membuat anak berbicara, seperti Sharing, Bercerita, Review, Dramatization, Rounds, Games, dan Brainstorming. Hal tersebut sesuai dengan pernyataan Trister yaitu anak dapat menikmati kegiatan circle time dengan mengikutsertakan anak secara langsung, seperti bercerita dan bermain. Selain itu sesuai dengan pendapat Essa yaitu guru dapat menggunakan Bercerita, Sharing, dan Review. Selain itu sesuai juga dengan pernyataan Burt yaitu Round dan Brainstorming. Berdasarkan pernyataan tersebut, maka kegiatan Sharing, Bercerita, Review, Dramatization, Rounds, Games, dan Brainstorming dapat digunakan ketika melakukan kegiatan circle time di dalam kelas karena semua kegiatan tersebut dapat melibatkan anak secara langsung untuk berbicara.

Kegiatan Sharing yaitu kegiatan dimana anak menceritakan pengalamannya, kegiatan Bercerita yaitu kegiatan dimana anak mengulang kembali cerita yang telah diceritakan guru, kegiatan Review adalah kegiatan dimana anak dan guru mengulas kembali kegiatan yang telah dilakukan, kegiatan Dramatization yaitu kegiatan dimana anak melakukan bermain peran, kegiatan Rounds adalah kegiatan dimana anak masing-masing anak melanjutkan apa yang guru katakan, kegiatan Games adalah kegiatan dimana 
guru dan anak melakukan permainan, dalam penelitian ini permainan yang dimainkan adalah permainan tebak gambar/ciri-ciri gambar, dan kegiatan Brainstorming adalah kegiatan dimana guru meminta anak untuk mengeluarkan pendapatnya mengenai apa yang diketahui tentang kegiatan yang akan dilaksanakan.

Kegiatan akan lebih baik jika didukung dengan media yang membantu ketika kegiatan belajar mengajar berlangsung. Media dibuat sesuai dengan tema yang akan dibahas, seperti media gambar seri dan gambar-gambar yang bersangkutan dengan tema yang sedang dibicarakan. Hal tersebut sesuai dengan pernyataan Grugeon yaitu agar circle time berjalan efektif, maka perlu menyediakan mainan yang banyak digemari anak saat berbicara atau bercerita.Media akan membuat pembelajaran yang berlangsung tidak monoton dan anak akan lebih jelas dalam memahami apa yang dipelajari.

Pada penelitian ini, pemilihan kegiatan menentukan peningkatan kemampuan berbicara anak. Pada siklus I, anak masih terbata-bata dalam berbicara, masih kurang jelas dalam menyatakan sesuatu, anak masih belum dapat menjawab pertanyaan yang diberikan, bahasa tubuh dan intonasi anak masih datar ketika berbicara. Hal tersebut membuat kurangnya kemampuan berbicara anak.
Pada siklus II, peneliti memberikan kegiatan yang lebih membuat anak dapat berbicara lebih banyak dan menggunakan media yang lebih baik dari sebelumnya, memberikan kesempatan yang lebih banyak kepada anak yang masih terbatabata dalam berbicara, lebih ekspresif lagi dalam mengungkapkan sesuatu, dan lebih sering mengungkapkan kalimat dengan menggunakan keterangan orang, tempat, dan waktu dan meminta anak mengulangi yang peneliti katakan. Seperti halnya yang dikemukakan oleh Trister yaitu agar kegiatan circle time efektif maka guru dapat mengubah, memperpendek, atau menghilangkan aktivitas kelompok yang membuat anak tidak berkerja atau menambahkan waktu di kegiatan yang disenangi anak. Oleh karena itu, peneliti mengubah kegiatan dengan memperbanyak kesempatan kepada anak yang masih terbata-bata. Selain itu berdasarkan pernyataan Grugeon terdapat saran dalam melakukan kegiatan circle time yaitu menggunakan media yang yang baik. Oleh karena itu, diharapkan kemampuan berbicara anak dapat lebih meningkat.

Pada siklus I, hanya beberapa anak yang terlibat aktif dalam berbicara selama kegiatan belajar mengajar berlangsung. Beberapa anak yang masih terbata-bata lebih banyak diam. Setelah siklus II, semua anak terlibat aktif dalam berbicara 
selama kegiatan belajar berlangsung. Keterlibatan aktif anak dalam berbicara dapat meningkatkan kemampuan berbicara anak.

Indikator yang dijadikan acuan dalam penelitian ini mengalami peningkatan. Hal tersebut dapat dilihat pada kemampuan berbicara anak pada saat pra penelitian yaitu anak masih memerlukan banyak bantuan peneliti dalam berbicara. Bahasa tubuh dan intonasi anak masih datar dalam mengungkapkan sesuatu, anak belum dapat menjawab pertanyaan yang diberikan dan belum dapat mengajukan pertanyaan. Anak juga masih terbata-bata dan tidak jelas dalam mengungkapkan sesuatu.

Setelah tindakan siklus I, kemampuan berbicara anak menunjukkan peningkatan. Peningkatan yang terjadi belum pada semua sub aspek. Sub aspek yang meningkat adalah pada pengertian kalimat dimana anak sudah dapat menjawab dengan tepat apa yang ditanyakan. Selanjutnya pada sub aspek kelancaran dan kejelasan dimana beberapa anak mulai berkembang dalam menyatakan sesuatu secara lancar dan jelas dengan menggunakan kata ganti orang.Hal tersebut terjadi karena pada setiap kegiatan yang dilakukan hanya mengembangkan beberapa aspek saja sehingga tidak semua aspek dapat meningkat.
Setelah tindakan pada siklus II, kemampuan berbicara anak mengalami peningkatan. Sub aspek yang meningkat adalah pengertian makna/kalimat yaitu tanak sudah mampu menjawab pertanyaan dari peneliti dengan tepat serta anak mulai berkembang dalam kemampuan mengajukan pertanyaan. Selanjutnya pada sub aspek kelancaran dan kejelasan dalam menyatakan sesuatu dengan lancar dan telah dapat menggunakan kata ganti orang, waktu, dan tempat ketika berbicara. Anak masih dalam tahap mulai berkembang pada aspek bahasa tubuh dan intonasi suara. Hal tersebut terjadi seperti halnya pada siklus I yaitu kegiatan yang diberikan tidak langsung dapat menstimulasi semua sub aspek serta kurang banyaknya kegiatan yang dapat menstimulasi bahasa tubuh dan intonasi suara anak dalam berbicara.

Selama penelitian, kegiatan yang disenangi anak adalah kegiatan becerita dan sharing karena kegiatan tersebut lebih membuat anak dapat mengeluarkan pendapatnya, terutama kegiatan sharing dimana anak diberi kesempatan untuk menceritakan pengalaman pribadinya, sehingga anak terlihat senang ketika melakukan kegiatan tersebut. Selain itu, peningkatan banyak terjadi pada Ar, Be, dan As. Peningkatan terjadi pada semua indikator baik saat siklus I maupun siklus II. Pada penelitian ini, terdapat pula anak yang mengalami peningkatan yang lambat 
yaitu Fa, Lut, dan Ta karena mendapatkan skor yang rendah pada tiap indikatornya. Menurut tutor, itu terjadi karena memang $\mathrm{Fa}$, Lut, dan Ta memang anak yang pendiam di dalam kelas dan tidak berbicara jika tidak ditanya terlebih dahulu.

Peningkatan kemampuan berbicara anak akan lebih baik lagi apabila kegiatan circle time dapat dilakukan secara rutin pada setiap kegiatan belajar mengajar berlangsung. Hal tersebut, akan membuat anak mendapatkan kesempatan yang lebih banyak dalam berbicara, dibanding dengan hanya memberikan buku paket kepada anak. Kemampuan berbicara penting bagi anak karena anak dapat mengungkapkan apa yang dirasakan. Hal tersebut seperti yang dikemukakan oleh Sonawat dan Francis yaitu berbicara bertujuan agar orang lain mengetahui apa yang dirasakan dan apa yang dibutuhkan. Berbicara juga dapat mengekspresikan emosi kepada orang lain. Oleh karena itu pentingnya kemampuan berbicara bagi anak karena menyangkut komunikasi dengan orang lain.

Selain dapat mengembangkan kemampuan berbicara anak, circle time juga dapat meningkatkan perkembangan sosial emosional anak. Hal tersebut sesuai dengan pernyataan Mosley yaitu circle time bertujuan memberikan kurikulum, perkembangan sosial dan emosional, pada saat yang sama, dapat membantu anakanak untuk memahami nilai-nilai moral yang universal dan praktik keterampilan pemecahan masalah. Oleh karena itu, pada kegiatan circle time anak juga akan belajar untuk mendengarkan orang lain, menghargai orang lain dan anak akan lebih merasa dihargai

Berdasarkan

pemaparan sebelumnya, maka dapat dikatakan bahwa kegiatan circle time dapat meningkatkan kemampuan berbicara anak usia 4-5 tahun di PAUD Tunas, Jakarta Selatan.

\section{KESIMPULAN DAN SARAN}

Berdasarkan hasil analisis data kuantitatif diperoleh presentase peningkatan siklus pra penelitian ke siklus I adalah $12 \%$. Dari data tersebut dapat dikatakan bahwa presentase siklus I mengalami peningkatan, hanya saja peningkatan belum mencapai presentase yang telah disepakati.Sebagaimana disampaikan pada interpretasi hasil analisis bahwa penelitian ini dikatakan berhasil jika terjadi peningkatan minimal 20\%, maka pada penelitian siklus I ini belum dapat dikatakan berhasil karena hasil peningkatan presentase belum tercapai.

$$
\text { Peneliti dan kolaborator }
$$

menyepakati agar tindakan dilanjutkan ke siklus II untuk mencapai peningkatan yang diharapkan yaitu sebesar $20 \%$. Berdasarkan hasil data siklus II diperoleh 
peningkatan presentase sebesar 25\%.Dari data tersebut dapat dikatakan bahwa peningkatan presentase siklus I ke siklus II mengalami peningkatan yang signifikan. Dengan demikian, maka dapat dinyatakan bahwa kegiatan circle time dapat meningkatan kemampuan berbicara anak usia 4-5 tahun di PAUD Tunas, Jakarta Selatan. Setelah memperoleh presentase kenaikan yang signifikan, maka penelitian dihentikan.

Berdasarkan hasil analisis data kualitatif, setelah tindakan siklus I, kemampuan berbicara anak menunjukkan peningkatan. Peningkatan terjadi pada aspek pengertian kalimat dimana anak sudah dapat menjawab dengan tepat apa yang ditanyakan. Beberapa anak mulai berkembang dalam menyatakan sesuatu secara lancar dan jelas.Beberapa anak masih kurang dalam kemampuan mengajukan pertanyaan dan dalam hal bahasa tubuh dan intonasi ketika berbicara.

Setelah tindakan pada siklus II, kemampuan berbicara anak mengalami peningkatan.Anak sudah mampu menjawab pertanyaan dari peneliti dengan tepat.Hampir semua anak sudah berkembang dalam menyatakan sesuatu dengan lancar dan telah dapat menggunakan kata ganti orang, waktu, dan tempat ketika berbicara.Anak mulai berkembang dalam kemampuan mengajukan pertanyaan.Anak juga sudah mulai berkembang dalam hal bahasa tubuh dan intonasi yang sesuai ketika berbicara.

Berdasarkan hasil analisis data kuantitatif dan kualitatif tersebut, maka peneliti dapat menyimpulkan bahwa penerapan circle time dapat meningkatkan kemampuan berbicara anak usia 4-5 tahun di PAUD Tunas, Jakarta Selatan.

\section{DAFTAR PUSTAKA}

Abdulhak, Ishak dan Ugi suprayogi. Penelitian Tindakan dalam Pendidikan Nonformal. (Bandung: Raja Grafindo Persada, 2012)

Aqib, dkk. Penelitian Tindakan Kelas (Bandung: Yrama Widya, 2010)

Arikunto, Suharsimin, Prosedur Penelitian: Suatu Pendekatan Praktis Edisi Revisi 2010 (Jakarta: Rineka Cipta, 2012)

Arsyad, Siddik. Model Pembelajaran Bercerita dengan CBSA. (Jakarta: PT Rosda Jayaputra, 2004)

Asmani, Jamal M.. Penelitian Tindakan Kelas. (Jogjakarta: Laksana, 2011) Berk, Laura E. Children Development. (New York: Pearson, 2006)

Bromley, Karen D'Angelo. Language Arts: Exploring Connection. (America: Allyn and Bacon, 1992)

Burk, Angela J. and M. Trika. Observing the Language Learner. (New York: International Reading Assosiation, 1985) 
Burt, Sian, et al. Six Years of Circle Time. (London: Lucky Duck, 2005)

Crain, William. Teori Perkembangan Konsep dan Aplikasi. (Yogyakarta: Pustaka Pelajar, 2007)

Daniel and James M.K. Exceptional children. (USA: Prentice Hall, 1978)

Dyer, Laura. Meningkatkan Kemampuan Berbicara Anak. (Jakarta: PT Bhuana Ilmu Populer, 2004)

Ekawarna. Penelitian Tindakan Kelas. (Jakarta: Gaung Persada, 2010)

Essa. Intoduction to Early Childhood Education. (Canada: Cengage Learning, 2008)

Gestwicki, Carol. Developmentally Appropriate Practice. (Canada: Thomson Delmar Learning, 2007)

Grugeon, Elizabeth, et al. Teaching Speaking and Listening in the Primary School. (London: David Fulton Publishers, 2005)

Hallahan and Kauffman. Exceptional Children Sixth Editio. (USA: Prentice Hall, 1994)

Herrick, Virgil and Leland Jacobs. Children and the Language Arts. (Prentice-hall, Inc)

Hildayani, Rini, dkk. Psikologi Perkembangan Anak. (Jakarta: Universitas Terbuka, 2011)
Jalongo, Mary Renck. Early Childhood Language Arts $4^{\text {th }}$ Edition. (Boston: Pearson Education, 2007)

Jamaris, Martini. Perkembangan dan Pengembangan Anak Usia Taman Kanak-kanak. (Jakarta: Grasindo, 2006)

Jarolimek, John and Clifford D. Foster. Teaching and Learning in the Elementary School. (New York: macmillan publishing, 1981)

Kusnandar. Penelitian Tindakan Kelas. (Jakarta: PT. Raja Grafindo Persada, 2008)

Levelt, Willem. Speaking from Intention to Articulation. (USA: Publication Data, 1989)

Masruroh, Farhatin. Aktualisasi Kecerdasan Verbal Linguistik Anak Usia Dini Melalui Pendekatan Beyond Centers and Circle Time (BBCT) di TK ABA NUR'AINI Ngampilan Yogyakarta. (Yogyakarta: UIN Sunan Kalijaga, 2011)

Moleong, Lexy J. Metode Penelitian Kualitatif Edisi Revisi. (Bandung: Remaja Rosdakarya, 2001)

Mosley, Jenny. Circle Time for Young Children. (New York: Routledge, 2005)

Mulyasa. Praktik Penelitian Tindakan Kelas. (Bandung: Remaja Rosdakarya, 2012)

Philipsen, Gerry. Speaking Culturally Exploration in Social 
Communication. (New York: Trister, Diane and Laura Colker. The Albany, 1992) Creative Curriculum for Early Childhood. (Washington DC:

Safari, M. A. Pengujian dan Penilaian Teaching Strategies Inc, 2001)

Bahasa dan Sastra Indonesia. (Jakarta: CV.Roda Pengetahuan, 2002)

Sanjaya, Wina. Penelitian Tindakan Kelas. (Jakarta: Kencana PrenanaGroup, 2009)

Santrock, John W. Child Development. (New York: Mc Graw Hill, 2009)

Smith, Charlie. Introducing Circle Time to Secondary Students : a seven lesson programme for 11 to 12 year olds. (Clifton, Bristol : Lucky Duck Publishing, (C2003)

Susanto, Ahmad. Perkembangan Anak Usia Dini. (Jakarta: Kencana Prenada Media Grup, 2011)

Syafaruddin. Pendidikan dan Pemberdayaan Masyarakat. (Medan: Perdana Publishing, 2012)

Syamsiyatun,Atri. "Upaya Meningkatkan Kemampuan Bicara Anak melalui Penggunaan Gambar Karya Anakdi TK Kartika IV-38 Depok Sleman“, Skripsi (Yogyakarta: PGPAUD, UNY, 2012)

Tarigan, Henry Guntur. Menyimak Sebagai Suatu Keterampilan Berbahasa. (Bandung: Angkasa, 2008)

Trawick, Jeffey and Smith. Early Childhood Development. (New Jersey: Merrill Prentice Hall, 2003) 